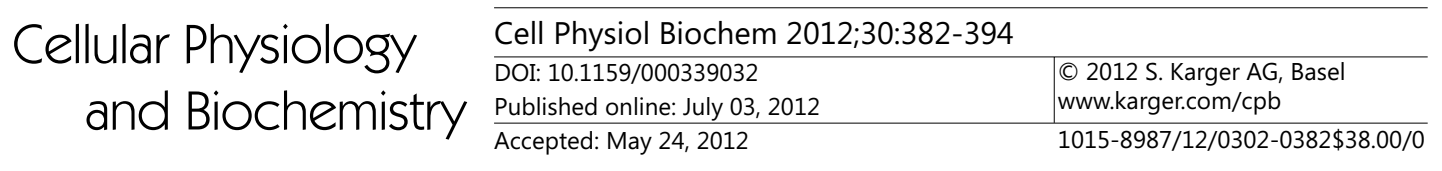

\title{
The Endocrine Disruptor 4-Nonylphenol Promotes Adipocyte Differentiation and Induces Obesity in Mice
}

\author{
Chan-juan Hao ${ }^{1,2}$ Xue-jia Cheng ${ }^{1,2}$ Hong-fei Xia ${ }^{1,2}$ Xu Ma $a^{1,2}$ \\ ${ }^{1}$ Reproductive and Genetic Center of National Research Institute for Family Planning, Beijing, ${ }^{2}$ Graduate \\ School, Peking Union Medical College, Beijing
}

\section{Key Words}

4-Nonylphenol (4-NP) • Adipocyte differentiation • Peroxisome proliferator-acivated receptor $\gamma($ PPAR $\gamma) \cdot$ Perinatal exposure $\cdot$ Obesity

\begin{abstract}
Background/Aim: The environmental obesogen hypothesis proposes that exposure to endocrine disruptors during developmental "window" contributes to adipogenesis and the development of obesity. Implication of environmental endocrine disruptor such as 4Nonylphenol (4-NP) on adipose tissue development has been poorly investigated. Methods: 3T3-L1 preadipocytes were incubated with different doses of 4-NP. Six-week-old C57BL/6J male mice received an intraperitoneal injection of vehicle, troglitazone or 4-NP $(0.5 \mathrm{mg} / \mathrm{kg})$. Gene expression of adipogenic regulators was analyzed. Pregnant mice were dosed by gavage with vehicle or $4-\mathrm{NP}(0.05,0.25$ or $0.5 \mathrm{mg} / \mathrm{kg})$ from day 12 of gestation until day 7 of lactation. The body weight, liver weight, fat mass, and serum lipids and glucose levels were measured in offspring at postnatal day 60. Results: Low concentration of 4-NP induced adipocyte differentiation, glycerol-3-phosphate dehydrogenase activity, and expression of peroxisome proliferator-acivated receptor $\gamma$ as well as its target genes required for adipogenesis. 4-NP perturbed key regulators of adipogenesis and lipogenic pathway in vivo. Perinatal exposure to 4-NP increased body weight, fat mass, and serum total cholesterol and glucose levels in offspring. Conclusions: 4-NP may be expected to increase the incidence of obesity and can act as a potential chemical stressor for obesity and obesity-related disorders.
\end{abstract}

Copyright (C) 2012 S. Karger AG, Basel 


\begin{tabular}{|c|c|c|}
\hline Cellular Phvsiol & Cell Physiol Biochem 2012;30:382-394 & \\
\hline and Riochemistry & $\begin{array}{l}\text { DOI: 10.1159/000339032 } \\
\text { Published online: July 03, } 2012\end{array}$ & $\begin{array}{l}\text { O } 2012 \text { S. Karger AG, Basel } \\
\text { www.karger.com/cpb }\end{array}$ \\
\hline
\end{tabular}

\section{Introduction}

Obesity causes or exacerbates many health problems, because it is associated with serious morbidities, including diabetes, hyperlipidemia, hypertension, cardiovascular disease and osteoarthritis. This has resulted in a significant increase in morbidity and mortality associated with metabolic syndrome [1-3]. Obesity is a problem for all ages, but it is of particular concern for children since the number of children and adolescents who are overweight, or at risk for being overweight, has risen in parallel with that reported in adults [4]. While the unbalance between caloric intake and expenditure is thought to be the most common cause of obesity, the reason for its surge might not be only related to excessive intake of food and a sedentary life [5]. Recently, there has been increased exposure to environmental chemicals in daily life and these chemicals have incidentally been taken by humans. Epidemiology studies indicate that the serum/urine concentrations of some of these chemicals have been found to be associated with the onset and incidence rate of obesity and diabetes [6-15]. This has led to the hypothesis that some of the numerous environmental pollutants that interfere with various aspects of metabolism might add one more risk factor for obesity and could be considered as "environmental obesogens". The "obesogens" inappropriately regulate lipid metabolism and adipogenesis promoting obesity [16-20].

Alkylphenol ethoxylates (APEs) are a class of nonionic surfactants that are widely used in the manufacturing of detergents, plastics, paints, cosmetics and pesticides [21, 22]. 4Nonylphenol (4-NP) is a microbial degradation product of nonylphenol ethoxylates, the most predominant member of alkylethoxylate surfactants [23, 24]. 4-NP is found in the wastewater and sludge of sewage treatment works and river sediments $[25,26]$, which is widely dispersed in the environment. The biological effects of 4-NP are hence of major concern but so far elusive. Previous studies indicated that 4-NP binds to estrogen receptors, resulting in its actions on the reproductive system [27-30]. To date, it is not clear whether the endocrine disruptor 4-NP affects the early differentiation of adipocytes, disrupts adipose tissue homeostasis and promotes development of obesity and obesity-associated cardiovascular disease.

In the present study, we tested the dose-dependent effects of 4-NP on adipocyte differentiation using the murine 3T3-L1 cell model. The confluent cultures of 3T3-L1 preadipocytes treated by 4-NP presented an increase in glycerol-3-phosphate dehydrogenase (GPDH) activity, suggesting that 4-NP can promote 3T3-L1 preadipocytes to differentiate into adipocyte. During differentiation, 4-NP induced the expression of peroxisome proliferatoracivated receptor $\gamma$ (PPAR $\gamma$ ) as well as its target genes required for adipogenesis. Consistent with in vitro results, we observed that 4-NP activated PPAR $\gamma$ and its target genes in vivo. To determine whether perinatal exposure to 4-NP could have an impact on filial adipogenesis, we defined adipose tissue deposition, serum lipids and glucose levels in offspring at postnatal day 60 (PND 60). Our results suggested that perinatal exposure to 4-NP might be expected to increase the incidence of obesity in offspring and could act as a potential chemical stressor for obesity and obesity-related disorders.

\section{Materials and Methods}

\section{Cell culture and treatment}

3T3-L1 mouse embryo fibroblasts, purchased from Institute of Biochemistry and Cell Biology, SIBS, CAS (Shanghai, China) were maintained in standard Dulbecco's modified Eagle's medium (DMEM; Hyclone, Logan, UT, USA) supplemented with 10\% Bovine Calf Serum (BCS; Invitrogen, Carlsbad, CA, USA) and 1\% penicillin/streptomycin. Cells were maintained as subconfluent cultures at $37^{\circ} \mathrm{C}$ in a humidified $5 \% \mathrm{CO}_{2}$ atmosphere with media changes every 2-3 days. 3T3-L1 fibroblasts, the unipotent preadipocytes, are the most widely used culture models in studying the progression of adipocyte differentiation [31]. For differentiation assays, cells were seeded at $6 \times 10^{4}$ cells per well into polylysine-coated 6 -well cell culture plates in 10\% fetal bovine serum (FBS; Invitrogen, Carlsbad, CA, USA)/DMEM, after which cultures were grown for 2 days and then treated by different concentrations of 4-NP (Sigma-Aldrich, St. Louis, MO, USA) or 


\begin{tabular}{|c|c|c|}
\hline Coll & Cell Physiol Biochem 2012;30:382-394 & \\
\hline and Biochemistry & $\begin{array}{l}\text { DOI: 10.1159/000339032 } \\
\text { Published online: July 03, } 2012\end{array}$ & $\begin{array}{l}\text { (c) } 2012 \text { S. Karger AG, Basel } \\
\text { www.karger.com/cpb }\end{array}$ \\
\hline
\end{tabular}

Table 1. Primer sequences for real-time PCR.

\begin{tabular}{lll}
\hline Gene & Forward & Reverse \\
\hline 18s rRNA & CTCTGTTCCGCCTAGTCCTG & AATGAGCCATTCGCAGTTTC \\
PPAR $\gamma$ & TGGGTGAAACTCTGGGAGATTC & AATTTCTTGTGAAGTGCTCATAGGC \\
C/EBP $\alpha$ & CCAAGAAGTCGGTGGACAAGA & CGGTCATTGTCACTGGTCAACT \\
aP2 & GAATTCGATGAAATCACCGCA & CTCTTTATTGTGGTCGACTTTCCA \\
FAS & TCGGGTGTGGTGGGTTTGGTGAAT & ACTTGGGGGCGTGAGATGTGTTGC \\
Srebf1 & GCCCCTGCCCACCTCAAACCT & ACTGGCACGGGCATCCTTCCTC \\
LPL & GTGTTGCTTGCCATTCTC & TCTCCTGATGACGCTGAT \\
\hline
\end{tabular}

troglitazone (Sigma-Aldrich, St. Louis, MO, USA) with $10 \mu \mathrm{g} / \mathrm{ml}$ insulin (Sigma-Aldrich, St. Louis, MO, USA) for 8 days. An 8-day treatment with $10 \mu \mathrm{g} / \mathrm{ml}$ insulin only served as a control. Media and drug treatments were renewed every 2 days. After 8 days, cells were stained with Oil Red 0 for lipid droplet accumulation as described below.

\section{Oil red 0 staining}

Cells were washed with sterile phosphate-buffered saline (PBS), fixed with $10 \%$ formaldehyde for 15 min at room temperature [32], washed with distilled water, and then stained with filtered Oil Red O solution ( $4 \mathrm{~g} /$ liter, 60\% isopropanol) for $15 \mathrm{~min}$. Excess stain was removed by washing three times with distilled water.

\section{GPDH activity}

Cells were rinsed with ice-cold PBS, scraped into $0.2 \mathrm{ml}$ extraction buffer (GPDH assay kit; TAKARA Bio Inc., Shiga, Japan), and centrifuged for $10 \mathrm{~min}$ at $4^{\circ} \mathrm{C}$. GPDH activity was assayed in the supernatant by monitoring the decrease in absorbance at $340 \mathrm{~nm}$ of NADH in the presence of dihydroxyacetone phosphate [33].

\section{Quantitative Real-Time PCR Analysis}

Total RNA from 3T3-L1 cells or C57BL/6J mouse tissues was isolated using RNeasy mini kit (QIAGEN, Germantown, MD, USA) and reversed transcribed using iScript cDNA synthesis kit (Bio-Rad, Hercules, CA, USA) according to the manufacturer's instructions. Triplicate cDNA samples ( $15 \mathrm{ng} /$ reaction) were analyzed by quantitative real-time PCR on an ABI prism 7000 thermal cycler (Applied Biosystems, Foster City, CA, USA) using FastStart universal SYBR Green master (Roche, Mannheim, Germany). Fold changes in expression levels were calculated after normalization to 18s rRNA. Gene-specific primers are shown in Table 1.

\section{Animal care and 4-NP exposure}

C57BL/6J mice were bred in the animal facility of NRIFP (National Research Institute for Family Planning) (mouse protocol SYXK 2009-0033) and housed in a room with a 12-hr light/dark cycle (lights on at 7:30 a.m. and off at 7:30 p.m.) with access to food and water ad libitum. All procedures were approved by the Institutional Animal Care and Use Committee of NRIFP. Six-week-old male mice received an intraperitoneal (ip) injection of 4-NP [0.5 mg/kg body weight (b.w.)], troglitazone $(0.5 \mathrm{mg} / \mathrm{kg}$ b.w.) or vehicle (olive oil) for 24 hours. Animals were sacrificed by decapitation. Liver and epididymal adipose tissue were collected for total RNA extraction as described above. Pregnant mice were dosed by gavage with 4-NP $(0.05,0.25$ or 0.5 $\mathrm{mg} / \mathrm{kg}$ b.w.) or vehicle (olive oil) from day 12 of gestation until day 7 of lactation (PND 7 of offspring). Pups were weaned at $3 \mathrm{wk}$ of age (PND 21) and maintained on standard rodent chow.

\section{Measurement of obesity parameters}

After 8-week-old pups were weighed, animals were sacrificed by asphyxia. Liver, epididymal/ parametrial and perirenal fat pads were harvested and weighed. Blood was collected by cardiac puncture after an overnight fasting. Blood glucose, serum total cholesterol and triglycerides were measured by 


\title{
Cellular Physiology and Biochemistry
}

\author{
Cell Physiol Biochem 2012;30:382-394 \\ \begin{tabular}{l|l}
\hline DOI: $10.1159 / 000339032$ & C 2012 S. Karger AG, Basel
\end{tabular} \\ Published online: July 03, 2012 \\ www.karger.com/cpb
}

colorimetric kit assays (Leadman, Beijing, China) and analyzed using a fully-automatic biochemistry analyzer (Hitachi, Tokyo, Japan).

Data analysis

cDNA samples analyzed by quantitative real-time PCR were performed in triplicate and were repeated three times. All data were obtained from at least three independent experiments. Data are represented as means \pm S.E.M., and $n$ indicates the number of experiments. Multiple group comparisons were performed using one-way analysis of variance (ANOVA). For studies examining obesity parameters in mice, data were analyzed statistically using ANOVA, and subsequent comparisons were performed using the Tukey-Kramer test, which allows for unequal sample sizes. All statistical procedures were carried out using SPSS software (version 16.0). A value of $P<0.05$ was considered statistically significant.

\section{Results}

\section{4-NP promotes 3T3-L1 preadipocyte differentiation}

In the murine 3T3-L1 preadipocyte cell model, adipogenic signals induce late differentiation markers PPAR $\gamma$ and CCAAT/enhancer-binding protein alpha (C/EBP $\alpha$ ), which drive terminal adipocyte differentiation and lipid accumulation [34-37]. We therefore examined the effects of 4-NP on the differentiation of 3T3-L1 preadipocyte and compared its effect to PPAR $\gamma$ agonist troglitazone. An 8-day treatment of 3T3-L1 preadipocyte with troglitazone in the presence of insulin strongly induced adipogenesis in a dose-dependent manner. Insulin alone had only mild effect, whereas the combination of insulin and 4-NP induced dose-dependent adipogenic effects, as evidenced by Oil Red 0 staining (Fig. 1A). The ability of 4-NP to promote adipogenesis was maximal at $10 \mu \mathrm{M}$, with no further enhancement at higher doses (data not shown).

In order to further explore the dose-response relationship, cellular GPDH activity was quantified to confirm the actions of 4-NP on adipocyte differentiation in the concentration range of $1 \mathrm{~nm}$ to $10 \mu \mathrm{M}$. The results showed that the cultures with insulin alone contained $2.37 \pm 0.24$ units GPDH activity/mg protein. The combination of 4-NP together with insulin caused a 2.2-fold to 3.5-fold increase in the concentration range of $100 \mathrm{~nm}$ to $10 \mu \mathrm{M}$ in a dosedependent manner, but the lower doses of 4-NP $(1 \mathrm{~nm}$ or $10 \mathrm{~nm})$ had no significant effect on GPDH activity in 3T3-L1 cells (Fig. 1B). Likewise, the presence of troglitazone also caused a 3.5-fold increase (Fig. 1B). Thus, 4-NP significantly promotes adipocyte differentiation in vitro.

\section{4-NP induces adipogenic regulators and markers in 3T3-L1 adipocytes}

To characterize the adipogenic actions of 4-NP, we performed gene expression analysis on adipogenic regulators by quantitative reverse transcriptase-PCR. Expression levels from cells treated with insulin alone and from cells differentiated with troglitazone or 4-NP in the presence of insulin were compared. Expression of $P P A R \gamma$ a nuclear receptor of ligandactivated transcription factor that not only is critical for adipogenesis, but also represents a specific marker of fat cell differentiation [37-39], was increased by 4-fold at the dose of $10 \mu \mathrm{M}$ troglitazone. In addition, the expression levels of its downstream target genes such as $A P 2$ (adipocyte-specific fatty acid binding protein) and $L P L$ (lipoprotein lipase) were upregulated by 18 -fold and 1.3-fold, respectively. Gene expression levels of PPAR $\gamma, a P 2$ and $L P L$ were significantly increased [by 3-fold, 2.7 -fold and 1.6-fold] at dose of $10 \mu \mathrm{M} 4-\mathrm{NP}$ compared with insulin alone (Fig. 2).

Overall, the results show that 4-NP combined with insulin activates transcriptional factors PPAR $\gamma$ as well as its target genes, thus promoting 3T3-L1 preadipocytes to differentiate into mature adipocytes.

\section{4-NP induces adipogenic regulators and markers in vivo}

The ability of 4-NP to regulate key modulators of adipogenesis and lipid homeostasis in vivo has not been previously examined. Therefore, we next asked whether 4-NP could 


\section{Cellular Physiology Cell Physiol Biochem 2012;30:382-394 \begin{tabular}{ll|l} 
and Biochemistry & $\begin{array}{l}\text { DOI: 10.1159/000339032 } \\
\text { Published online: July 03, 2012 }\end{array}$ & $\begin{array}{l}\text { O 2012 S. Karger AG, Basel } \\
\text { www.karger.com/cpb }\end{array}$ \\
& Hao/Cheng/Xia/Xu Ma: 4-Nonylphenol Promotes Adipogenesis
\end{tabular}}

A

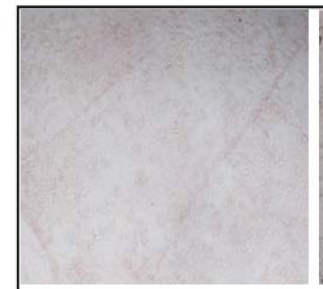
DMSO

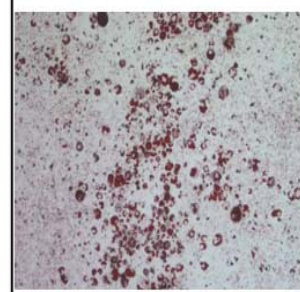

Ins + Trog $1 \mu \mathrm{M}$

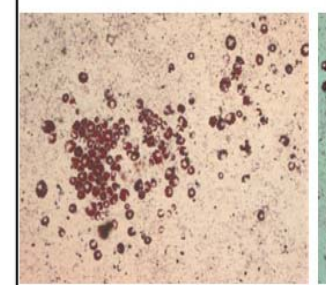

Ins + 4-NP $1 \mu \mathrm{M}$

B

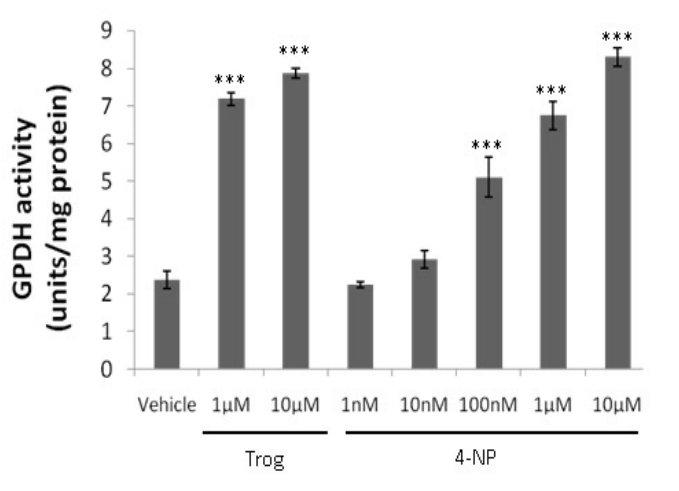

Fig. 1. 4-NP induces adipogenesis in 3T3-L1 cells. Confluent 3T3-L1 cells were treated for 8 days in the presence of DMSO, $10 \mu \mathrm{g} / \mathrm{ml}$ insulin alone or insulin plus ligands at the indicated concentrations. (A) Differentiated adipocytes were evidenced by Oil Red 0 staining. Scale bar represents $200 \mu \mathrm{m}$. (B) GPDH activity was determined in cell lysates. Values are mean \pm S.E.M. $(\mathrm{n}=3) .{ }^{* * *} P<0.001$. Ins, insulin; Trog, Troglitazone.

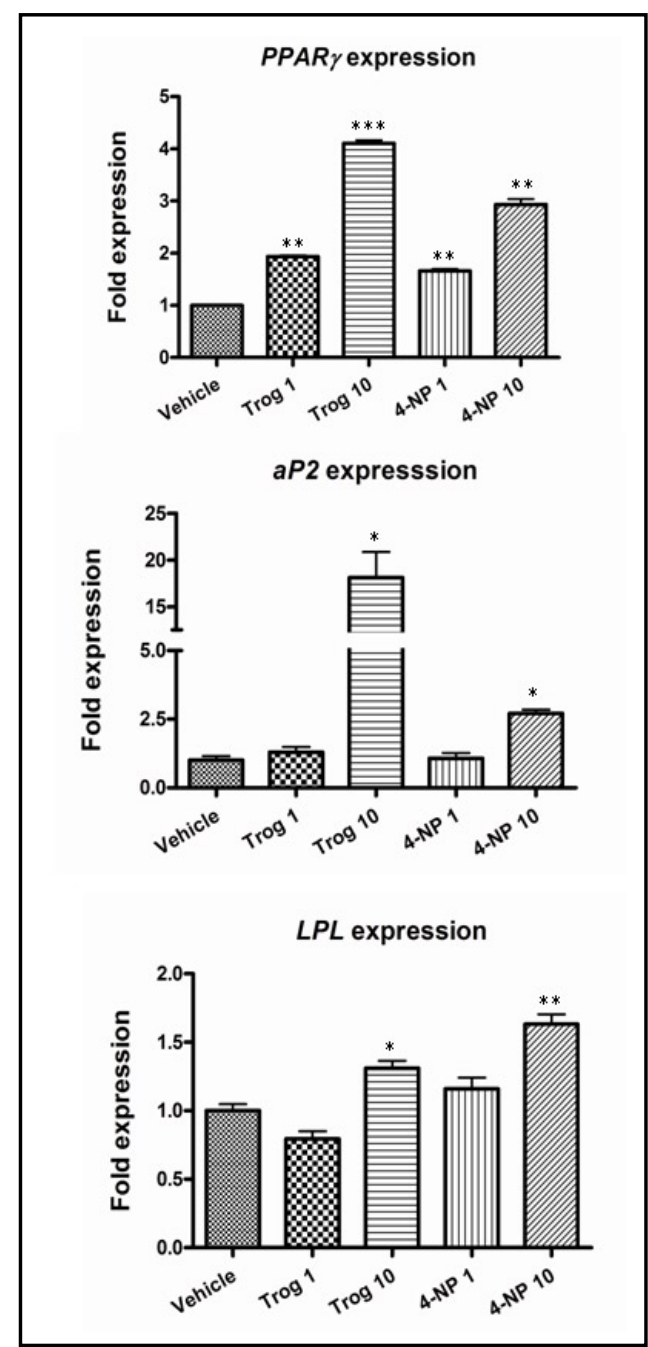

Fig. 2. Effects of 4-NP on mRNA expression of adipogenic modulators in mature 3T3-L1 adipocytes. 3T3-L1 cells were treated for 8 days with $10 \mu \mathrm{g} / \mathrm{ml}$ insulin alone or a combination of $10 \mu \mathrm{g} / \mathrm{ml}$ insulin and ligands at the indicated concentrations (1-10 $\mu \mathrm{M}$ of Trog or 4-NP). mRNA expression levels of PPAR $\gamma, \mathrm{aP} 2$ and $L P L$ were detected by quantitative real-time PCR. Expression levels were standardized to levels of 18s $r R N A$ mRNA by calculating cycle thresholds (Ct). The data shown are representative of three independent experiments. Values are mean \pm S.E.M. $(\mathrm{n}=3) .{ }^{*} P<0.05,{ }^{* *} P<0.01,{ }^{* * *} P<0.001$. Trog, Troglitazone.

perturb expression of critical regulators including transcriptional mediators PPAR, $\mathrm{C} / \mathrm{EBP} \alpha$ and Srebf1 (sterol regulatory element binding factor 1) as well as known target genes of PPAR $\gamma$ signaling. Epididymal adipose tissue and liver of 6-wk-old male mice dosed for $24 \mathrm{~h}$ with 4-NP $(0.5 \mathrm{mg} / \mathrm{kg}$ b.w.), troglitazone $(0.5 \mathrm{mg} / \mathrm{kg} \mathrm{b.w})$, or vehicle (olive oil) were dissected for total RNA extraction and target genes analysis. 


\section{Cellular Physiology and Biochemistry

Fig. 3. In vivo induction of adipogenic modulators. Six-week-old C57BL/6J male mice were dosed with vehicle (olive oil), troglitazone $(0.5 \mathrm{mg} / \mathrm{kg}$ b.w.) or $4-\mathrm{NP}$ ( $0.5 \mathrm{mg} / \mathrm{kg}$ b.w.) by ip injection. Animals were sacrificed after 24 hours and cDNA was prepared from epididymal adipose tissue or liver for quantitative real-time PCR analysis. Expression levels were standardized to levels of 18 s $r R N A$ mRNA by calculating cycle thresholds $(\mathrm{Ct})$. The data shown are representative of threeindependent experiments. Values are mean \pm S.E.M. $(\mathrm{n}=3) .{ }^{*} P<0.05,{ }^{*} P<0.01,{ }^{* * *} P<0.001$. Trog, Troglitazone.

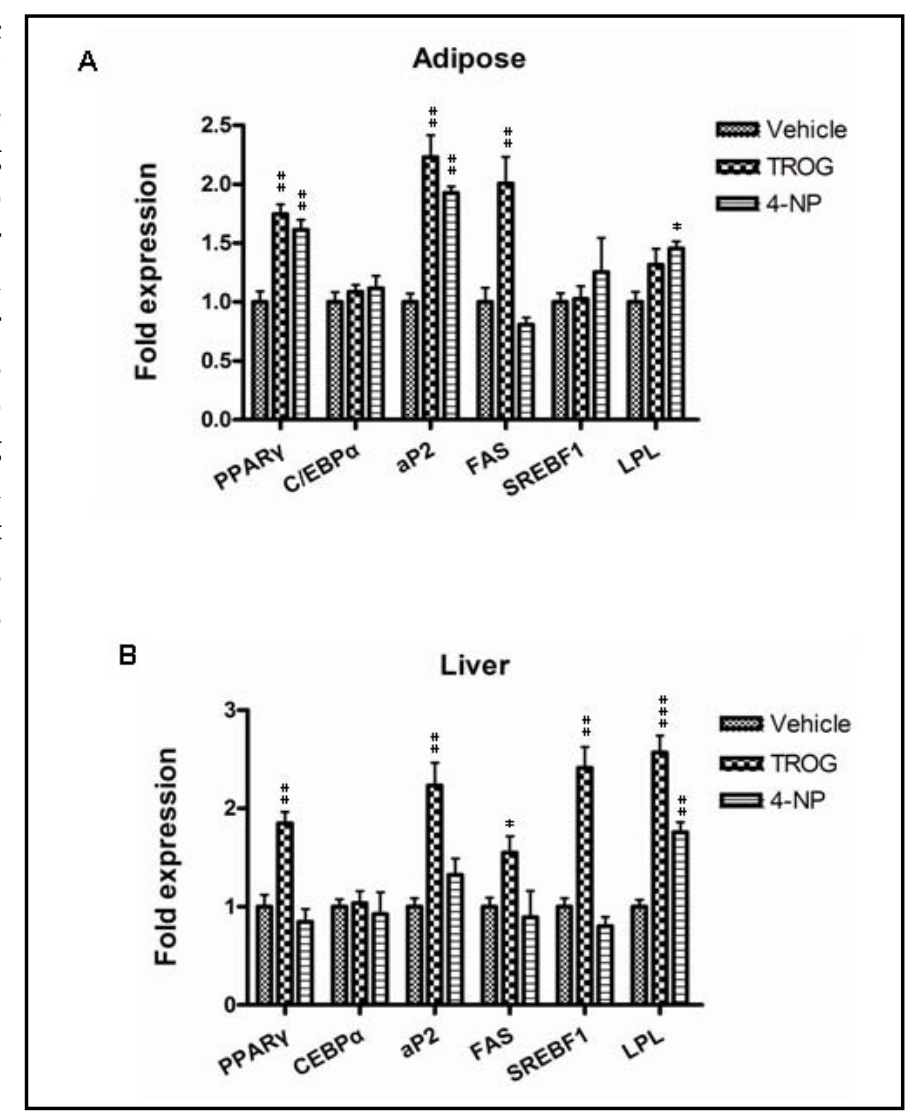

A pronounced expression increase caused by 4-NP was observed for the adipogenic markers $P P A R \gamma, a P 2$ and $L P L$, whereas troglitazone significantly induced expression of $P P A \mathrm{R} \gamma$ as well as the late adipogenic markers such as $a P 2$ and FAS (fatty acid sythetase) in adipose tissue (Fig. 3A). Liver is a key organ involved in metabolism, as it controls synthesis of many nutrients including lipids and carbohydrates. The results showed that troglitazone significantly induced expression of PPAR , aP2, FAS and LPL [by 1.8-fold, 2.2-fold, 1.6-fold and 2.6-fold] in liver tissue. In addition, troglitazone was also able to clearly up-regulate the expression level of Srebf1 transcript, another critical transcriptional mediator during adipogenesis. In contrast, 4-NP only weakly but significantly induced the expression of $L P L$ in liver (Fig. 3B).

Taken together, these data indicate that 4-NP exposure activates lipogenic gene expression, and 4-NP may be potential adipogenc agents in vivo.

\section{Effects of perinatal exposure to 4-NP on obesity in female offspring}

Based on its ability to promote 3T3-L1 adipocyte differentiation, and in vivo activation responses, we reasoned that perinatal exposure to 4-NP, which is a sensitive period of adipose tissue development [40], would disrupt normal endocrine signals and promote adipogenesis. Therefore, pregnant mice were dosed by gavage with $4-\mathrm{NP}(0.05,0.25 \mathrm{or} 0.5 \mathrm{mg} / \mathrm{kg}$ b.w. $)$ or vehicle (olive oil) from day 12 of gestation until day 7 of lactation (PND 7 of offspring). Eightweek-old pups were weighed. In females, the mean body weight increased by $17 \%$ at 0.05 $\mathrm{mg} / \mathrm{kg}$ b.w. and $8 \%$ at $0.25 \mathrm{mg} / \mathrm{kg}$ b.w., respectively, compared with the control group. The body weight at the dose of $0.5 \mathrm{mg} / \mathrm{kg}$ b.w. did not significantly increase (Fig. 4A).

To determine whether the increased body weight reflects body composition changes, we weighed liver and two distinct fat pads (parametrial and perirenal). Liver weight increased by $15 \%$ at $0.05 \mathrm{mg} / \mathrm{kg}$ b.w. $(0.95 \pm 0.03 \mathrm{~g})$ compared with vehicle controls $(0.82 \pm 0.03 \mathrm{~g})$. The other two groups did not exhibit significant increase in liver weight (Fig. 4B). The increase of mean adipose tissue weight was the highest at the dose of $0.25 \mathrm{mg} / \mathrm{kg}$ b.w.. Parametrial $(0.26 \pm 0.03 \mathrm{~g})$ and perirenal $(0.10 \pm 0.01 \mathrm{~g})$ fat pads weight increased by $73 \%$ and $100 \%$ 


\section{Cellular Physiology Cell Physiol Biochem 2012;30:382-394 \\ \begin{tabular}{ll|l} 
and Biochemistry & $\begin{array}{l}\text { DOI: 10.1159/000339032 } \\
\text { Published online: July 03, 2012 }\end{array}$ & $\begin{array}{l}\text { O 2012 S. Karger AG, Basel } \\
\text { www.karger.com/cpb }\end{array}$ \\
Hao/Cheng/Xia/Xu Ma: 4-Nonylphenol Promotes Adipogenesis
\end{tabular}}
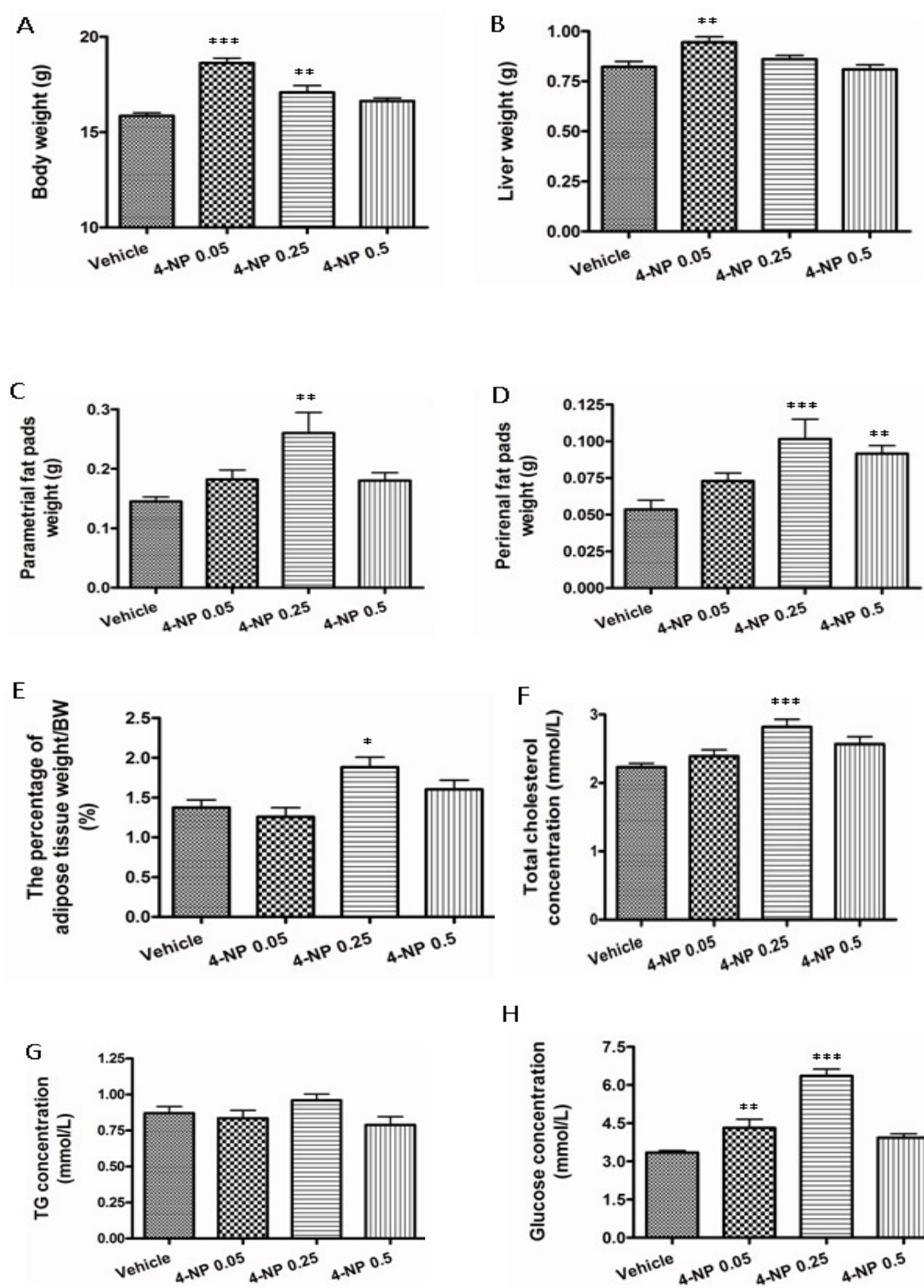

$\mathrm{H}$

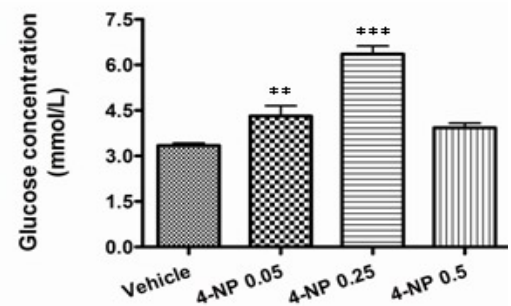

Fig. 4. Effects of 4-NP exposure on body weight, fat stores and metabolism in female offspring. Pregnant mice were dosed by gavage with vehicle (olive oil) or 4 -NP $(0.05,0.25$ or $0.5 \mathrm{mg} / \mathrm{kg}$ b.w.) from day 12 of gestation until day 7 of lactation (PND 7 of offspring). Obesity parameters of 8-week-old female offspring were measured. (A) Body weight. (B) Liver weight. (C) Parametrial fat pads weight. (D) Perirenal fat pads weight. (E) The percentage of adipose tissue weight to body weight. (F) Serum levels of total cholesterol. (G) Serum levels of triglycerides (TG). (H) Serum glucose levels. Values are mean \pm S.E.M. ( $\mathrm{n}=16$ vehicle-treated female pups from five litters; $\mathrm{n}=12$ 4-NP-treated ( $0.05 \mathrm{mg} / \mathrm{kg}$ b.w.) female pups from three litters; $\mathrm{n}=104$ NP-treated ( $0.25 \mathrm{mg} / \mathrm{kg}$ b.w.) female pups from three litters; $\mathrm{n}=9$ 4-NP-treated ( $0.5 \mathrm{mg} / \mathrm{kg}$ b.w.) female pups from three litters). BW, body weight; ${ }^{*} P<0.05,{ }^{* *} P<0.01,{ }^{* * *} P<0.001$.

compared with controls (parametrial: $0.15 \pm 0.01 \mathrm{~g}$; perirenal: $0.05 \pm 0.01 \mathrm{~g}$ ) (Fig. 4C and 4D). The 4-NP-treated group at the higher dose $(0.5 \mathrm{mg} / \mathrm{kg}$ b.w.) showed significant increase by $80 \%$ in perirenal fat mass, but not parametrial fat mass, while the adipose tissue weight at lower dose $(0.05 \mathrm{mg} / \mathrm{kg}$ b.w.) did not differ significantly from the control group (Fig. 4C and 4D). The percentage of adipose tissue weight to body weight was significantly higher at 0.25 


\begin{tabular}{rlr} 
Cellular Physiology & \multicolumn{1}{c}{ Cell Physiol Biochem 2012;30:382-394 } \\
\cline { 2 - 3 } and Biochemistry & \begin{tabular}{l} 
DOI: 10.1159/000339032 \\
\cline { 2 - 3 }
\end{tabular} & $\begin{array}{l}\text { Published online: July 03, 2012 } \\
\text { Hao/Cheng/Xia/Xu Ma: 4-Nonylphenol Promotes Adipogenesis } \\
\text { www.karger.com/cpb }\end{array}$
\end{tabular}

\begin{tabular}{|c|c|c|c|c|}
\hline & $\begin{array}{l}\text { Vehicle } \\
(\mathrm{n}=16)^{\mathrm{a}}\end{array}$ & $\begin{array}{c}\text { 4-NP } \\
(0.05 \mathrm{mg} / \mathrm{kg} \text { b.w. }) \\
(\mathrm{n}=10)\end{array}$ & $\begin{array}{c}4-\mathrm{NP} \\
(0.25 \mathrm{mg} / \mathrm{kg} \text { b.w. }) \\
(\mathrm{n}=10)\end{array}$ & $\begin{array}{c}4-\mathrm{NP} \\
(0.5 \mathrm{mg} / \mathrm{kg} \text { b.w. }) \\
(\mathrm{n}=15)\end{array}$ \\
\hline Body weight (g) & $19.62 \pm 0.31^{\circ}$ & $23.22 \pm 0.42^{\text {*** }}$ & $20.10 \pm 0.50$ & $20.56 \pm 0.17$ \\
\hline Liver weight (g) & $0.97 \pm 0.01$ & $1.09 \pm 0.02^{* * *}$ & $0.99 \pm 0.01$ & $0.99 \pm 0.02$ \\
\hline $\begin{array}{l}\text { Epididymal } \\
\text { fat pads (g) }\end{array}$ & $0.23 \pm 0.01$ & $0.34 \pm 0.02^{*}$ & $0.26 \pm 0.02$ & $0.28 \pm 0.02$ \\
\hline Perirenal fat pads $(\mathrm{g})$ & $0.06 \pm 0.01$ & $0.06 \pm 0.00$ & $0.07 \pm 0.01$ & $0.07 \pm 0.01$ \\
\hline $\begin{array}{l}\text { The percentage } \\
\text { (adipose tissue weight / } \\
\text { BW) }(\%)\end{array}$ & $1.81 \pm 0.07$ & $1.70 \pm 0.11$ & $1.68 \pm 0.12$ & $1.73 \pm 0.12$ \\
\hline Cholesterol $(\mathrm{mmol} / \mathrm{L})$ & $2.53 \pm 0.08$ & $2.48 \pm 0.08$ & $2.62 \pm 0.06$ & $2.69 \pm 0.06$ \\
\hline $\mathrm{TG}(\mathrm{mmol} / \mathrm{L})$ & $1.29 \pm 0.07$ & $1.31 \pm 0.08$ & $1.36 \pm 0.12$ & $1.08 \pm 0.03$ \\
\hline Glucose $(\mathrm{mmol} / \mathrm{L})$ & $3.65 \pm 0.09$ & $4.27 \pm 0.52$ & $4.08 \pm 0.31$ & $4.04 \pm 0.16$ \\
\hline
\end{tabular}

Table 2. Measurements of obesity parameters, serum lipids and glucose in male offspring. Pregnant mice were dosed by gavage with vehicle (olive oil) or 4-NP $(0.05,0.25$ or 0.5 $\mathrm{mg} / \mathrm{kg}$ b.w.) from day 12 of gestation until day 7 of lactation (PND 7 of offspring). The body weight, liver weight, fat pads weight, the percentage of adipose tissue weight to body weight, and serum lipids and glucose levels were measured in 8-week-old male offspring. ${ }^{*} P<0.05,{ }^{* *} P<0.01,{ }^{* * *} P<0.001$. BW, body weight; TG, triglycerides; ${ }^{\text {a Numbers of }}$ parentheses show the number of mice; ${ }^{b}$ mean \pm S.E.M.

$\mathrm{mg} / \mathrm{kg}$ b.w. (1.88 $\pm 0.12 \%$ ), but not the other two groups (0.05: $1.26 \pm 0.11 \%$; $0.5: 1.60 \pm 0.11$ $\%)$, than that in the control group ( $1.37 \pm 0.09 \%)$ (Fig. 4E).

To assess whether these alteration in body weight and adipose tissue weight were related to changes in circulating levels of nutrients, we measured the levels of serum total cholesterol, triglycerides (TG) and blood glucose. Consistent with the excessive adipose tissue, serum total cholesterol and blood glucose levels at the dose of $0.25 \mathrm{mg} / \mathrm{kg}$ b.w. were increased about $26 \%$ and $90 \%$ compared with the controls (Fig. $4 \mathrm{~F}$ and $4 \mathrm{H}$ ), whereas serum levels of TG did not significantly increase (Fig. 4G). The higher $(0.5 \mathrm{mg} / \mathrm{kg}$ b.w.) or lower $(0.05$ $\mathrm{mg} / \mathrm{kg} \mathrm{b.w.)} \mathrm{dose} \mathrm{of} \mathrm{4-NP} \mathrm{did} \mathrm{not} \mathrm{lead} \mathrm{to} \mathrm{the} \mathrm{increase} \mathrm{in} \mathrm{serum} \mathrm{levels} \mathrm{of} \mathrm{total} \mathrm{cholesterol} \mathrm{and}$ TG (Fig. 4F and 4G). Glucose levels, while higher at the dose of $0.05 \mathrm{mg} / \mathrm{kg}$ b.w. $(4.31 \pm 0.33$ $\mathrm{mmol} / \mathrm{L})$ than in the control $(3.35 \pm 0.08 \mathrm{mmol} / \mathrm{L})$, remained within the physiological range (Fig. 4H).

Taken together, these results suggest that perinatal exposure to 4-NP at the dose of $0.25 \mathrm{mg} / \mathrm{kg}$ b.w. is more effective in altering some parameters of obesity and inducing the development of obesity in female offspring.

\section{Effects of perinatal exposure to 4-NP on obesity in male offspring}

In males, the mean body weight and liver weight of 4-NP-treated group at the dose of $0.05 \mathrm{mg} / \mathrm{kg}$ b.w. increased by $18 \%$ and $12 \%$, respectively, compared with the control group. Although the percentage of adipose tissue weight to body weight did not significantly increase compared with the control group, the epididymal fat pads weight at $0.05 \mathrm{mg} / \mathrm{kg}$ b.w. was higher than that in the control group. Whereas serum lipid and glucose levels at $0.05 \mathrm{mg} / \mathrm{kg}$ b.w. did not differ significantly from the control group. For the other two groups ( 0.25 or $0.5 \mathrm{mg} / \mathrm{kg}$ b.w.), 4-NP exposure did not lead to obese phenotype, in which body weight, body composition, serum lipids and glucose levels did not differ significantly from the control group (Table 2).

Overall, the data indicate that perinatal exposure to 4-NP at the dose of $0.05 \mathrm{mg} / \mathrm{kg}$ b.w. shows a relatively moderate but clear low-dose effect in male offspring. 


\section{Cellular Physiology and Biochemistry}

Cell Physiol Biochem 2012;30:382-394

\begin{tabular}{l|l}
\hline DOI: $10.1159 / 000339032$ & (c) 2012 S. Karger AG, Basel \\
\end{tabular}

Published online: July 03, 2012 www.karger.com/cpb

\section{Discussion}

In the study, we have shown the concentration-dependent effects of 4-NP on adipocyte differentiation using the murine 3T3-L1 cell model. 4-NP induced the expression of PPARã as well as its target genes required for adipogenesis. Consistent with in vitro results, 4-NP also activated PPAR $\gamma$ and its target genes in adipose tissue. Furthermore, perinatal exposure to 4-NP increased body weight, fat mass, serum total cholesterol and glucose levels in offspring. Thus, our results suggested that perinatal exposure to 4-NP might be expected to increase the incidence of obesity in offspring and could act as a potential chemical stressor for obesity and obesity-related disorders.

So far, the effects of 4-NP on the differentiation of 3T3-L1 preadipocytes have not been fully clear, while Wada et al. reported that treatment with nonylphenol stimulated the accumulation of triacylglycerol in mature adipocytes differentiated from 3T3-L1 preadipocytes [41]. We showed herein that 3T3-L1 preadipocytes were induced into mature adipocytes by 4-NP in a dose-dependent manner. Furthermore, the results of GPDH activity, which is the late-stage differentiation marker, reflected the differentiation state of 3T3-L1 preadipocytes in a quantitative level. In this study, we tried to induce 3T3-L1 preadipocytes by $4-\mathrm{NP}$ at the dose of $100 \mu \mathrm{M}$ and $1 \mathrm{mM}$, respectively, combined with insulin. Nevertheless, the observation results showed the presence of cell debris (data not shown), which may reflect a limitation of preference of 4-NP used in vitro. We therefore infer that higher dose of 4-NP than $10 \mu \mathrm{M}$ might possess cytotoxicity activity and lead to cell death.

During adipogenesis, fibroblast-like preadipocytes differentiate into lipid-laden and insulin-responsive adipocytes. The process occurs in several stages and involves a cascade of transcriptional factors, among which PPAR $\gamma$ is considered the crucial determinant of adipocyte fate [37-39]. In the present study, the effect of 4-NP on adipocytes differentiation was confirmed by a series of molecular evidence. 4-NP between 1-10 $\mu \mathrm{M}$ effectively induced the expression of PPAR $\gamma$ in 3T3-L1 cells. The newly formed PPAR $\gamma$ was functionally active, since its increase stimulated the expression of $L P L$ and $a P 2$ genes, two of its specific targets $[37,39]$. In this study, we found that FAS (fatty acid synthetase), another downstream target gene of PPAR $\gamma$, was significantly less induced, indicating that efficacy of gene induction by 4-NP may depend on the promoter context. In addition, another adipogenesis transcription factor Srebf1, which regulates transcription of many lipid genes and participates in the generation of endogenous PPAR $\gamma$ ligands [37, 39], was significantly less induced (data not shown). We therefore postulate that 4-NP might not activate Srebf1 to occupy the promoters of key adipocyte genes.

In adipose tissue, 4-NP activated the expression of $P P A R \gamma$ as well as its downstram target genes such as $L P L$ and $a P 2$, which is consistent with the results in 3T3-L1 preadipocytes model. However, 4-NP had no effect on PPAR $\gamma$ transcription while troglitazone induced the expression of $P P A R \gamma$ in liver. The explanation is that 4-NP may not be a strong agonist compared with the direct PPAR $\gamma$ ligand troglitazone, because the expression increase of $P P A R \gamma$ as well as its target gene $a P 2$ induced by 4-NP is significant but relatively minor compared to the robust response observed with troglitazone (Fig. 2).

Although much proof has demonstrated that low dose of endocrine disrupting chemicals (EDCs) during development can interfere with normal function of endocrine system, consequently inducing overweight and obesity later in life [40, 42-45], it is not fully understood whether in utero 4-NP exposure promotes the onset of obesity and metabolic syndrome in offspring. In the study, pregnant mice were dosed by gavage with 4-NP $(0.05,0.25$ or $0.5 \mathrm{mg} / \mathrm{kg}$ b.w.) or vehicle (olive oil) during the critical stages of adipocyte differentiation (developmental "window"). Our results demonstrated for the first time that perinatal and postnatal exposure to 4-NP significantly induced the development of obesity in female offspring at the dose of $0.25 \mathrm{mg} / \mathrm{kg} \mathrm{b.w.}$. Although 4-NP treatment at $0.05 \mathrm{mg} / \mathrm{kg}$ b.w. induced the increase of body weight, the fat mass and the percentage of fat mass to body weight did not differ significantly from the control group. Consequently, the used dose $(0.05 \mathrm{mg} / \mathrm{kg}$ b.w. $)$ had no effect on obesity in female offspring, since obesity is characterized by the accumulation of excessive adipose tissue mass in the body. However, it is currently 


\section{Cellular Physiology Cell Physiol Biochem 2012;30:382-394 \\ \begin{tabular}{ll|l} 
and Biochemistry & $\begin{array}{l}\text { DOI: 10.1159/000339032 } \\
\text { Published online: July 03, } 2012\end{array}$ & $\begin{array}{l}\text { C) 2012 S. Karger AG, Basel } \\
\text { www.karger.com/cpb }\end{array}$ \\
\cline { 2 - 3 } Hao/Cheng/Xia/Xu Ma: 4-Nonylphenol Promotes Adipogenesis
\end{tabular}}

unknown whether the increased adiposity at $0.25 \mathrm{mg} / \mathrm{kg}$ b.w. results from an increase in adipocyte precursor cell number, enhanced adipocyte differentiation from the same number of precursors, an increase in adipocyte size without an increase in number, or some combination of these. The treatment of 4-NP at the higher dose $(0.5 \mathrm{mg} / \mathrm{kg} \mathrm{b.w}$.) did not alter the parameters of obesity compared with the control group. We thus infer that there may be a nonmonotonic dose-response increase in the development of obesity in female offspring. We also observed that the 4-NP exposure at $0.25 \mathrm{mg} / \mathrm{kg} \mathrm{b.w}$. was more effective than the other two groups in increasing serum total cholesterol and glucose levels. Therefore, the accumulation of excessive fat mass could disrupt the lipid and glucose homeostasis.

Our present data showed that higher dose $(0.5$ or $0.25 \mathrm{mg} / \mathrm{kg}$ b.w.) of 4-NP exposure did not alter the parameters of obesity in male offspring, but the treatment at $0.05 \mathrm{mg} / \mathrm{kg}$ b.w. increased the body weight, liver weight and epididymal fat mass, which exhibiting a lowdose effect on male offspring. Although the serum lipids and glucose levels at $0.05 \mathrm{mg} / \mathrm{kg}$ b.w. were similar to those in control group, we infer that a statistical significance continues to be further studied for the long-term consequences.

Although the mechanism by which in utero exposure to 4-NP promotes obesity differently in female and male offspring is unclear, it may be caused by the precise dose and timing of exposure to 4-NP. So far, there have been some reports on the differences in responses to endocrine disruptors between female and male offspring born to exposed dams. For example, the continuous exposure to bisphenol A (BPA), an estrogenic endocrine-disrupting chemical, during perinatal and postnatal periods caused the development of obesity in offspring, but the effective exposure dose is gender-specific [44-46]. Miyawaki et al. noted that a 10-fold higher dose was inefficient in inducing overstorage of fat in females but was efficient in increasing fat storage in males. However, the lower exposure dose effectively induced obesity and hyperlipidemia in female offspring. This led authors to conclude that BPA caused a nonmonotonic and inverted U-shaped dose-response increase in females [45]. Consistent with the finding, Rubin et al. reported that, in female rats exposed perinatally to BPA, the lower dose $(0.1 \mathrm{mg} / \mathrm{kg}$ b.w.) produced a larger effect on body weight relative to the higher dose $(1.2 \mathrm{mg} / \mathrm{kg}$ b.w.) [46]. In addition, sex-dependent and dose-dependent differences in the development of obesity in response to early postnatal exposure to DES, an estrogenic compound with structural similarities to BPA, have been reported. Their studies demonstrated treatment of female mice with DES on days 1-5 of neonatal life using a dose of $1 \mu \mathrm{g}$ DES/day increased body weight and the percent of body fat at 4 months of age. In contrast, males exposed to DES during that time period showed a decrease in body weight and the percent of body fat relative to controls at 4 months of age [19]. Unlike the lower dose of DES, a higher neonatal DES dose $(1 \mathrm{mg} /$ day) caused a significant decrease in body weight of female mice about 2 months of age [40]. Additionally, a recent study showed that genistein, one of the most abundant phytoestrogens in the human diet, at pharmacologically high doses did indeed inhibit adipose tissue fat deposition, while at low doses, similar to those found in Western and Eastern diets, in soy milk or in food supplements containing soy, it induced increased adipose tissue fat deposition, especially in males. Further, this increase in adipose tissue fat deposition by genistein was correlated with mild peripheral insulin resistance [47]. A key concept in the field of endocrine disruption is that there may be non-traditional dose-response curves such as an inverted " $U$ " or even multiple " $U$ " shaped curves, making it impossible to predict responses environmental exposure range [48]. In our studies, lower dose $(0.05 \mathrm{mg} / \mathrm{kg}$ b.w.) induced the increase of body weight and fat mass in male offspring to exposed dams, while relatively moderate dose $(0.25 \mathrm{mg} / \mathrm{kg}$ b.w. $)$ promoted the development of obesity in female offspring. This suggests that the obesity induced by 4NP exposure follows the non-traditional dose-response curves. Therefore, the susceptibility to endocrine disruptors might be highly specific for a given dose and timing of exposure, and the kind of endocrine disruptors used.

In conclusion, the present study demonstrates that direct exposure to 4-NP through placenta and milk increases adipose storage, serum lipid and glucose levels in offspring, confirming the observations in 3T3-L1 cell model. Perinatal exposure to 4-NP might be expected to increase the incidence of obesity in offspring and could act as a potential chemical 


\section{Cellular Physiology and Biochemistry \\ Cell Physiol Biochem 2012;30:382-394 \\ \begin{tabular}{l|l}
\hline DOI: $10.1159 / 000339032$ & C 2012 S. Karger AG, Basel
\end{tabular} \\ Published online: July 03, 2012 \\ www.karger.com/cpb}

stressor for obesity and obesity-related disorders. Moreover, precise molecular mechanisms involved in the adipogenesis stimulated by 4-NP are needed to be further explored, and the long-term consequences of 4-NP exposure on body weight homeostasis are needed to be further understood.

\section{Acknowledgements}

This work was supported by grants from National Basic Research Program of China (No. 2007CB511905) and National Research Institute for Family Planning (No. 2009GJSSJKA06).

\section{Conflicts of interest}

The authors declared no conflict of interest.

\section{References}

1 Collins S: Overview of clinical perspectives and mechanisms of obesity. Birth Defects Res A Clin Mol Teratol 2005;73:470-471.

2 Mokdad AH, Ford ES, Bowman BA, Dietz WH, Vinicor F, Bales VS, Marks JS: Prevalence of obesity, diabetes, and obesity-related health risk factors, 2001. JAMA 2003;289:76-79.

3 Mokdad AH, Serdula MK, Dietz WH, Bowman BA, Marks JS, Koplan JP: The spread of the obesity epidemic in the United States, 1991-1998. JAMA 1999;282:1519-1522.

4 Ogden CL, Flegal KM, Carroll MD, Johnson CL: Prevalence and trends in overweight among US children and adolescents, 1999-2000. JAMA 2002;288:1728-1732.

5 Desvergne B, Feige JN, Casals-Casas C: PPAR-mediated activity of phthalates: A link to the obesity epidemic? Mol Cell Endocrinol 2009;304:43-48.

6 Goncharov A, Haase RF, Santiago-Rivera A, Morse G: Akwesasne Task Force on the Environment, McCaffrey RJ, Rej R, Carpenter DO: High serum PCBs are associated with elevation of serum lipids and cardiovascular disease in a Native American population. Environ Res 2008;106:226-239.

7 Gladen BC, Ragan NB, Rogan WJ: Pubertal growth and development and prenatal and lactational exposure to polychlorinated biphenyls and dichlorodiphenyl dichloroethene. J Pediatr 2000;136:490-496.

8 Vasiliu 0, Cameron L, Gardiner J, Deguire P, Karmaus W: Polybrominated biphenyls, polychlorinated biphenyls, body weight, and incidence of adult-onset diabetes mellitus. Epidemiology 2006;17:352-359.

9 Lee DH, Lee IK, Jin SH, Steffes M, Jacobs DR Jr: Association between serum concentrations of persistent organic pollutants and insulin resistance among nondiabetic adults: results from the National Health and Nutrition Examination Survey 1999-2002. Diabetes Care 2007;30:622-628.

10 Lee DH, Steffes MW, Jacobs DR Jr: Can persistent organic pollutants explain the association between serum gamma-glutamyltransferase and type 2 diabetes? Diabetologia 2008;51:402-407.

11 Pelletier C, Doucet E, Imbeault P, Tremblay A: Associations between weight loss-induced changes in plasma organochlorine concentrations, serum $\mathrm{T}(3)$ concentration, and resting metabolic rate. Toxicol Sci 2002;67:46-51.

12 Smink A, Ribas-Fito N, Garcia R, Torrent M, Mendez MA, Grimalt JO, Sunyer J: Exposure to hexachlorobenzene during pregnancy increases the risk of overweight in children aged 6 years. Acta Paediatr 2008;97:14651469.

13 Stahlhut RW, van Wijngaarden E, Dye TD, Cook S, Swan SH: Concentrations of urinary phthalate metabolites are associated with increased waist circumference and insulin resistance in adult U.S. males. Environ Health Perspect 2007;115:876-882.

14 Hatch EE, Nelson JW, Qureshi MM, Weinberg J, Moore LL, Singer M, Webster TF: Association of urinary phthalate metabolite concentrations with body mass index and waist circumference: a cross-sectional study of NHANES data, 1999-2002. Environ Health 2008;7:27. 


\section{Cellular Physiolosy Cell Physiol Biochem 2012;30:382-394

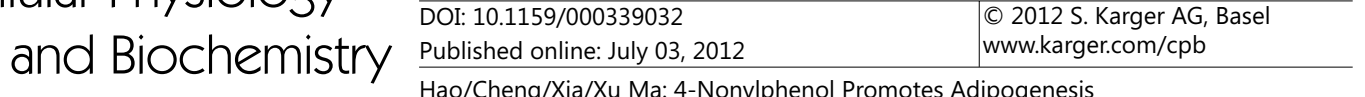 Hao/Cheng/Xia/Xu Ma: 4-Nonylphenol Promotes Adipogenesis}

15 Takeuchi T, Tsutsumi O, Ikezuki Y, Takai Y, Taketani Y: Positive relationship between androgen and the endocrine disruptor, bisphenol A, in normal women and women with ovarian dysfunction. Endocr J 2004;51:165-169.

16 Baillie-Hamilton PF: Chemical toxins: a hypothesis to explain the global obesity epidemic.J Altern Complement Med 2002;8:185-192.

17 Heindel JJ: Endocrine disruptors and the obesity epidemic. Toxicol Sci 2003;76:247-249.

18 Grün F, Blumberg B: Perturbed nuclear receptor signaling by environmental obesogens as emerging factors in the obesity crisis. Rev Endocr Metab Disord 2007;8:161-171.

19 Newbold RR, Padilla-Banks E, Jefferson WN, Heindel JJ: Effects of endocrine disruptors on obesity. Int J Androl 2008;31:201-208.

20 Tremblay A, Chaput JP: About unsuspected potential determinants of obesity. Appl Physiol Nutr Metab 2008;33:791-796.

21 Naylor CG, Mieure JP, Adams WJ, Weeks JA, Castaldi FJ, Ogle LD, Romano RR: Alkylphenol etoxylates in the environment. J Am Oil Chem Soc 1992;69:695-703.

22 Tolls J, Kloepper-Sams P, Sijm DT: Surfactant bioconcentration-a critical review. Chemosphere 1994;29:693717.

23 Naylor CG: Environmental fate and safety of nonylphenol ethoxylates. Tex Chem Color 1995;27:29-33.

24 Nimrod AC, Benson WH: Environmental estrogenic effects of alkylphenol ethoxylates. Crit Rev Toxicol 1996;26:335-364.

25 Giger W, Brunnen PH, Schaffer C: 4-Nonylphenol in sewage sludge: Accumulation of toxic metabolites from nonionic surfactants. Science 1984;225:623-625.

26 Hernando MD, Mezcua M, Gómez MJ, Malato 0, Agüera A, Fernández-Alba AR: Comparative study of analytical methods involving gas chromatography-mass spectrometry after derivatization and gas chromatographytandem mass spectrometry for the determination of selected endocrine disrupting compounds in wastewaters. J Chromatogr A 2004;1047:129-135.

27 Chapin RE, Delaney J, Wang Y, Lanning L, Davis B, Collins B, Mintz N, Wolfe G: The effects of 4-nonylphenol in rats: A multigeneration reproduction study. Toxicol Sci 1999;52:80-91.

28 Laws, SC, Carey SA, Ferrell JM, Bodman GJ, Cooper RL: Estrogenic activity of octylphenol, nonylphenol, bisphenol A and methoxychlor in rats. Toxicol Sci 2000;54:156-167.

29 Nagao T, Wada K, Marumo H, Yoshimura S, Ono H: Reproductive effects of nonylphenol in rats after gavage administration: a two-generation study. Reprod Toxicol 2001;15:293-315.

30 Odum J, Pyrah IT, Soames AR, Foster JR, Van Miller JP, Joiner RL, Ashby J: Effects of p-nonylphenol (NP) diethylstilboestrol (DES) on the alderley Park (Alpk) rat: Comparison of mammary gland and uterus sensitivity following oral gavage or implanted mini-pumps. J Appl Toxicol 1999;19:367-378.

31 Ntambi JM, Young-Cheul K: Adipocyte differentiation and gene expression. J Nutr 2000;130:3122S-3126S.

32 Hanlon PR, Ganem LG, Cho YC, Yamamoto M, Jefcoate CR: AhR- and ERK-dependent pathways function synergistically to mediate 2,3,7,8-tetrachlorodibenzo-p-dioxin suppression of peroxisome proliferatoractivated receptor-gamma 1 expression and subsequent adipocyte differentiation. Toxicol Appl Pharmacol 2003;189:11-27.

33 Wise LS, Green H: Participation of one isozyme of cytosolic glycerophosphate dehydrogenase in the adipose conversion of 3T3 cells. J Biol Chem 1979;254:273-275.

34 Lane MD, Tang QQ Jiang MS: Role of the CCAAT enhancer binding proteins (C/EBPs) in adipocyte differentiation. Biochem Biophys Res Commun 1999;266:677-683.

35 Tang QQ Otto TC, Lane MD: CCAAT/enhancer binding protein beta is required for mitotic clonal expansion during adipogenesis. Proc Natl Acad Sci USA 2003;100:850-855.

36 Tang QQ Lane MD: Activation and centromeric localization of CCAAT/enhancer-binding proteins during the mitotic clonal expansion of adipocyte differentiation. Genes Dev 1999;13:2231-2241.

37 Lefterova MI, Lazar MA: New developments in adipogenesis. Trends Endocrinol Metab 2009;20:107-114.

38 Tontonoz P, Spiegelman BM: Fat and beyond: the diverse biology of PPARgamma. Annu Rev Biochem 2008;77:289-312.

39 Farmer SR: Transcriptional control of adipocyte formation. Cell Metab 2006;4: 263-273.

40 Newbold RR: Impact of environmental endocrine disrupting chemicals on the development of obesity. Hormones (Athens) 2010;9:206-217. 


\section{Cellular Physiology \\ Cell Physiol Biochem 2012;30:382-394 and Biochemistry \begin{tabular}{l|l}
\hline DOI: $10.1159 / 000339032$ & C 2012 S. Karger AG, Basel
\end{tabular} www.karger.com/cpb}

41 Wada K, Sakamoto H, Nishikawa K, Sakuma S, Nakajima A, Fujimoto Y, Kamisaki Y: Life style-related diseases of the digestive system: endocrine disruptors stimulate lipid accumulation in target cells related to metabolic syndrome. J Pharmacol Sci 2007;105:133-137.

42 Grün F, Watanabe H, Zamanian Z, Maeda L, Arima K, Cubacha R, Gardiner DM, Kanno J, Iguchi T, Blumberg B: Endocrine-disrupting organotin compounds are potent inducers of adipogenesis in vertebrates. Mol Endocrinol 2006;20:2141-2155.

43 Arsenescu V, Arsenescu RI, King V, Swanson H, Cassis LA: Polychlorinated biphenyl-77 induces adipocyte differentiation and proinflammatory adipokines and promotes obesity and atherosclerosis. Environ Health Perspect 2008;116:761-768.

44 Somm E, Schwitzgebel VM, Toulotte A, Cederroth CR, Combescure C, Nef S, Aubert ML, Hüppi PS: Perinatal exposure to bisphenol a alters early adipogenesis in the rat. Environ Health Perspect 2009;117:1549-1555.

45 Miyawaki J, Sakayama K, Kato H, Yamamoto H, Masuno H: Perinatal and postnatal exposure to bisphenol a increases adipose tissue mass and serum cholesterol level in mice. J Atheroscler Thromb 2007;14:245-252.

46 Rubin BS, Murray MK, Damassa DA, King JC, Soto AM: Perinatal exposure to low doses of bisphenol A affects body weight, patterns of estrous cyclicity, and plasma LH levels. Environ Health Perspect 2001;109:675680.

47 Penza M, Montani C, Romani A, Vignolini P, Pampaloni B, Tanini A, Brandi ML, Alonso-Magdalena P, Nadal A, Ottobrini L, Parolini O, Bignotti E, Calza S, Maggi A, Grigolato PG, Di Lorenzo D: Genistein affects adipose tissue deposition in a dose-dependent and gender-specific manner. Endocrinology 2006;147:5740-5751.

48 vom Saal FS, Akingbemi BT, Belcher SM, Birnbaum LS, Crain DA, Eriksen M, Farabollini F, Guillette LJ Jr, Hauser R, Heindel JJ, Ho SM, Hunt PA, Iguchi T, Jobling S, Kanno J, Keri RA, Knudsen KE, Laufer H, LeBlanc GA, Marcus M, McLachlan JA, Myers JP, Nadal A, Newbold RR, Olea N, Prins GS, Richter CA, Rubin BS, Sonnenschein C, Soto AM, Talsness CE, Vandenbergh JG, Vandenberg LN, Walser-Kuntz DR, Watson CS, Welshons WV, Wetherill Y, Zoeller RT: Chapel Hill bisphenol A expert panel consensus statement: integration of mechanisms, effects in animals and potential to impact human health at current levels of exposure. Reprod Toxicol 2007;24:131138. 